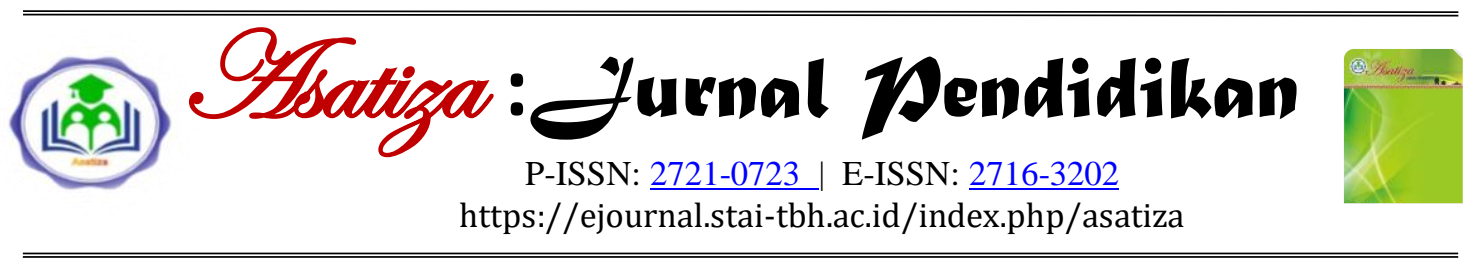

\title{
Pengaruh Penggunaan Pendekatan Pembelajaran Kelompok terhadap Hasil Belajar Akidah Akhlak Siswa
}

\begin{tabular}{|c|c|}
\hline \multicolumn{2}{|c|}{$\begin{array}{l}\text { *Al Afif Hazmar }{ }^{\mathbf{1}, \mathbf{a}} \text {, Marlian Marlian } \mathbf{2 , \mathbf { b }} \\
\text { 1,2, STAI Madinatun Najah Rengat, Indragiri Hulu, Riau, Indonesia } \\
\text { a a afifhazmar@ gmail.com, }{ }^{\mathrm{b}} \text { marlianramli03@ gmail.com }\end{array}$} \\
\hline & \multirow{5}{*}{$\begin{array}{l}\text { Abstract } \\
\text { This study aims to determine the difference between the learning } \\
\text { outcomes of Akidah Akhlah using the Collaborative learning approach } \\
\text { and the conventional learning approach at Madrasah Tsanawiyah Negeri } \\
\text { Pekan Heran, West Rengat District, Riau of Indonesia. Experimental } \\
\text { methods were used in this study, while data collection techniques used } \\
\text { observation, tests, and documentation. The results showed that the use of } \\
\text { the Collaborative learning approach was very good at } 88.46 \% \text {. The } \\
\text { experimental class was also categorically very good by } 85.48 \% \text {, while } \\
\text { the control class was categorically as good only by } 78.39 \% \text {. There was a } \\
\text { significant difference between the learning outcomes using the } \\
\text { Collaborative learning approach and the conventional one. This study } \\
\text { illustrated that the } t \text { value is greater than the } t \text { table at a significant level } \\
\text { of } 5 \% \text { or } 2.5688>2,00030 \text {. }\end{array}$} \\
\hline Histori Artikel: & \\
\hline & \\
\hline $\begin{array}{ll}\text { Disetujui } & : 01 / 09 / 2021 \\
\text { Diterbitkan : 30/09/2021 }\end{array}$ & \\
\hline & \\
\hline & \multirow{3}{*}{$\begin{array}{l}\text { Abstrak } \\
\text { Penelitian ini bertujuan untuk mengetahui perbedaan antara hasil belajar } \\
\text { akidah akhlak siswa menggunakan pendekatan pembelajaran kelompok } \\
\text { dengan metode konvensional di Madrasah Tsanawiyah Negeri Pekan } \\
\text { Heran Kecamatan Rengat Barat. Metode Eksperimen digunakan dalam } \\
\text { penelitian ini, sedangkan teknik pengumpulan data menggunakan } \\
\text { observasi, tes dan dokumentasi. Hasil penelitian menunjukkan bahwa } \\
\text { Penggunaan pendekatan pembelajaran kelompok dikategorikan sangat } \\
\text { baik ( } 80 \% \text { a } 100 \% \text { ) yaitu 88,46\%. Hasil belajar siswa kelas eksperimen } \\
\text { juga dikategorikan sangat baik yaitu 85,48, sedangkan hasil belajar siswa } \\
\text { kelas kontrol hanya dikategorikan baik yaitu 78,39. Terdapat perbedaan } \\
\text { yang signifikan antara hasil belajar yang diajar dengan pendekatan } \\
\text { pembelajaran kelompok dengan hasil belajar siswa yang diajar dengan } \\
\text { menggunakan metode konvensional, hal ini dilihat dari nilai t lebih besar } \\
\text { dari pada t tabel pada taraf signifikan 5\% yaitu 2,5688 >2,00030. }\end{array}$} \\
\hline $\begin{array}{l}\text { DOI: } \\
\text { https://doi.org/10.46 } \\
\text { asatiza.v2i3.360 }\end{array}$ & \\
\hline & \\
\hline
\end{tabular}

Cara mensitasi artikel:

Hazmar, A. A., \& Marlian, M. (2021). Pengaruh penggunaan pendekatan pembelajaran kelompok terhadap hasil belajar akidah akhlak siswa. Asatiza: Jurnal Pendidikan, 2(3), 162-169. https://doi.org/10.46963/asatiza.v2i3.360

\section{PENDAHULUAN}

Di dalam proses belajar mengajar, guru sebagai pengajar dan siswa sebagai subjek belajar dituntut adanya profil kualifikasi tertentu dalam hal pengetahuan, kemampuan, dan sikap, agar proses itu dapat berlangsung dengan efektif dan efisien. Istilah pendekatan berasal dari bahasa Inggris approach yang salah satu artinya adalah "Pendekatan". Dalam pengajaran, approach diartikan sebagai a way of beginning something "cara memulai sesuatu". Karena itu, pengertian pendekatan dapat diartikan cara 
memulai pembelajaran. Dan lebih luas lagi, pendekatan berarti seperangkat asumsi mengenai cara belajar-mengajar. Pendekatan merupakan titik awal dalam memandang sesuatu, suatu filsafat, atau keyakinan yang kadang kala sulit membuktikannya. Pendekatan ini bersifat aksiomatis. Aksiomatis artinya bahwa kebenaran teori yang digunakan tidak dipersoalkan lagi.

Penelitian ini bertujuan untuk mengetahui bagaimana pengaruh penggunaan pendekatan pembelajaran kelompok yang dilakukan oleh guru terhadap hasil belajar siswa di Madrasah Tsanawiyah Negeri Pekan Heran Kecamatan Rengat Barat. Dengan pendekatan kelompok mereka diharapkan memiliki kesadaran bahwa hidup ini ternyata hidup ini saling membutuhkan dan saling tergantung antara satu dengan yang lainnya. tidak ada makhluk hidup yang terus menerus dapat mencukupi dirinya tanpa bantuan orang lain.

Selain itu penelitian ini juga bertujuan untuk mengetahui hasil belajar siswa. Guru mempunyai peranan yang sangat penting dalam perkembangan dan kemajuan anak didiknya. Dari sinilah guru dituntut untuk dapat menjalankan tugas dengan sebaik-baiknya. Untuk dapat mencapai tujuan pengajaran yang diharapkan, guru harus pandai memilih pendekatan, metode serta media pembelajaran yang tepat dan sesuai dengan kebutuhan anak didik, supaya anak didik merasa senang dalam proses belajar mengajar berlangsung.

Pendidikan pada dasarnya merupakan sebuah upaya untuk membangun kecerdasan manusia baik secara kognitif, afektif dan psikomotorik, khususnya sekolah dasar bertujuan untuk membentuk karakter yang baik. (Indriana \& Sasmiati, 2019)

Pembelajaran dapat diartikan sebagai setiap upaya yang sistematik dan sengaja untuk menciptakan agar terjadi kegiatan interaksi edukatif antara dua pihak, yaitu peserta didik (warga belajar) dan pendidik (sumber belajar) yang melakukan kegiatan membelajarkan. (Rohmayanti, Yulistio, \& Utomo, 2019)

Dengan pendekatan pembelajaran yang tepat akan dapat membangkitkan motivasi belajar siswa, sehingga akan mendukung pencapaian hasil belajar lebih optimal. Uraian tersebut menunjukkan bahwa pendekatan pembelajaran yang dilakukan guru telah mempengaruhi seluruh aspek kehidupan, termasuk sistem pendidikan, proses pembelajaran, meskipun dalam derajat yang berbedabeda sehingga mempengaruhi hasil belajar yang dicapai oleh siswa. (Dimyati \& Mudjiono, 2012)

Hasil belajar adalah kemampuankemampuan yang dimiliki siswa setelah menerima pengalaman belajarnya. Hasil belajar merupakan tujuan yang dirumuskan sebelum proses belajar mengajar dilaksanakan. Pada umumnya hasil belajar meliputi pengetahuan, sikap dan keterampilan. Hasil belajar yang akan diperoleh siswa setelah menempuh belajarnya atau proses belajar mengajar. (Sudjana, 2012)

Dalam memahami peserta didik maka guru akan mengetahui cara mengelola pembelajaran siswa atau dengan kata lain membelajarkan siswa. Pengelolaan pembelajaran siswa dimulai 
dari perencanaan dan pelaksanaan pembelajaran, dan mengevaluasi hasil belajar. (Pingge \& Wangid, 2016)

Komponen utama adalah guru dan siswa, sedangkan komponen pendukung adalah sarana dan prasarana yang mendukung terwujudnya proses pembelajaran. (Sharni \& dkk, 2020).

Thabroni mengatakan hasil belajar adalah pola-pola perbuatan, nilai-nilai, pengertian-pengertian, sikap-sikap, apresiasi serta keterampilan. Hasil belajar merupakan pengalaman yang diperoleh siswa selama belajar sehingga akan menghasilkan nilai-nilai, norma-norma, pengertian-pengertian, sikap-sikap, apresiasi-apresiasi serta keterampilan tertentu setelah menyelesaikan belajarnya. (Thobroni \& dkk, 2011)

Dalam pembelajaran ini kelompok siswa bekerja sebagai sebuah tim yang memiliki tujuan yang sama, dengan demikian kelompok siswa bekerja sama dalam tim untuk memastikan bahwa seluruh anggota tim telah mencapai tujuan yang telah ditetapkan. (Waluya, 2015)

Madrasah Tsanawiyah Negeri Pekan Heran merupakan salah satu sekolah yang ada di Kecamatan Rengat Barat juga sangat memperhatikan hasil belajar pada siswanya. Guru di Madrasah Tsanawiyah tersebut sudah menerapkan pembelajaran kelompok pada siswa. Akan tetapi pendekatan pembelajaran kelompok yang digunakan pada kelas kontrol belum maksimal dan masih menggunakan pendekatan konvensional, hal ini dapat dilihat berdasarkan observasi awal yang dilakukan peneliti masih ditemui gejalagejala bahwa: (1) Masih ada sebagian guru belum membagi kelas menjadi beberapa kelompok yang terdiri dari 4-6 siswa dengan kemampuan yang berbeda-beda, (2) Masih ada sebagian guru belum mengemukakan tugas setiap kelompok kepada ketua kelompok atau langsung kepada semua siswa, (3) Masih ada sebagian guru belum mengemukakan peraturan dan tata tertib serta saat memulai dan mengakhiri kegiatan kerja kelompok, (4) Masih ada sebagian guru belum mengawasi, memonitor, dan bertindak sebagai fasilitator selama siswa melakukan kerja kelompok, (5) Masih ada hasil evaluasi peserta didik yang di bawah Kriteria Ketuntasan Minimal (KKM).

\section{METODE}

Metode yang digunakan dalam tulisan ini adalah eksperimen yang dimaksudkan untuk mengetahui ada tidaknya akibat dari "sesuatu" yang dikenakan pada subjek selidik. Dengan kata lain tulisan ini mencoba meneliti ada tidaknya hubungan sebab akibat dengan pendekatan kuantitatif, sehingga dalam menganalisis datanya digunakan analisis statistik.

Lokasi penelitian dilaksanakan di Madrasah Tsanawiyah Negeri Pekan Heran Kecamatan Rengat Barat Kabupaten Indragiri Hulu tahun 2020 dengan 31 orang peserta didik kelas VII-4 sebagai kelas eksperimen dan 31 orang Peserta Didik Kelas VII-5 sebagai kelas kontrol sehingga sampel berjumlah 62 orang peserta didik.

Teknik pengumpulan data yang digunakan adalah observasi yaitu pengambilan data dengan menggunakan mata tanpa ada pertolongan alat standar lain untuk keperluan tersebut (Nazir, 
2013). Kegiatan pencatatan dalam hal ini adalah merupakan bagian dari kegiatan pengamatan. Metode ini digunakan untuk mendapatkan data tentang pengaruh penggunaan pendekatan pembelajaran kelompok terhadap hasil belajar siswa. Teknik pengumpulan data yang kedua yaitu: Tes adalah serentetan pertanyaan atau latihan serta alat lain yang digunakan untuk mengukur keterampilan, pengetahuan, intelegensi, kemampuan atau bakat yang dimiliki oleh individu atau kelompok (Sugiyono, 2011).

Tes yang digunakan dalam penelitian ini adalah tes tertulis untuk mengukur kemampuan peserta didik. Adapun teknik pengumpulan data yang ketiga adalah dokumentasi, yaitu merupakan mencari data mengenai hal-hal atau variabel yang berupa cacatan, transkrip, buku, surat kabar-kabar, majalah, prasasti, notulen rapat, lengger, agenda, dan sebagainya (Arikunto, 2012). Dokumentasi tidak menggunakan instrumen, karena dokumentasi digunakan hanya untuk menghimpun data yang berkaitan dengan catatan-catatan sekolah terkait.

Teknik analisis data yang digunakan adalah tes " $t$ " yang berpegang pada taraf signifikan $5 \%$.

\section{HASIL DAN PEMBAHASAN}

Langkah pertama adalah mengetahui hasil observasi. Untuk memudahkan penulis dalam mencari persentase, maka penulis membaginya menjadi 4 (empat) standar kategorisasi, yakni (Riduwan, 2004):

1. Sangat Baik $(80 \%-100 \%)$

2. Baik $(60 \%-79 \%)$

3. Cukup baik $(40 \%-59 \%)$
4. Kurang baik $(0 \%-39 \%)$

Observasi yang penulis lakukan ini berlangsung selama 5 (lima) hari. Dari observasi yang penulis lakukan itu dapat disimpulkan sebagai berikut:

Dari hasil observasi pertama terhadap guru akidah akhlak diperoleh jawaban "Ya" sebanyak 7 buah $(53,85 \%)$, jawaban "Tidak" diperoleh sebanyak 6 buah $(46,15 \%)$. Dari hasil observasi kedua diperoleh jawaban "Ya" sebanyak 9 buah $(69,23 \%)$, jawaban "Tidak" diperoleh sebanyak 4 buah (30,77\%). Dari hasil observasi ketiga diperoleh jawaban "Ya" sebanyak 10 buah (76,92\%), jawaban "Tidak" diperoleh sebanyak 3 buah $(23,08 \%)$. Dari hasil observasi keempat diperoleh jawaban "Ya" sebanyak 11 buah (84,62\%), jawaban "Tidak" diperoleh sebanyak 2 buah (15,38\%). Sedangkan dari hasil observasi kelima diperoleh jawaban "Ya" sebanyak 13 buah (100\%), jawaban "Tidak" diperoleh sebanyak 0 buah (0\%).

Rekapitulasi hasil observasi tentang penggunaan pendekatan pembelajaran kelompok diperoleh:

1. Jumlah kumulatif option ya $=50$ atau $384,62 \%$ dari jumlah keseluruhan aspek.

2. Jumlah kumulatif option tidak $=15$ atau $115,38 \%$ dari jumlah keseluruhan aspek.

Berdasarkan jumlah kumulatif dari masing-masing option, maka diperoleh jumlah $n=65$ yakni jumlah dari seluruh option. Hasil ini diperoleh dengan menjumlahkan kumulatif dari option ya (A) dan tidak (B).

Untuk memasukkan ke rumus persentase rata-rata kualitatif hanya 
tinggal mencari f. Untuk mencari f terlebih dahulu masing-masing option akan diberi bobot, yakni option ya diberi bobot, dan option tidak diberi bobot 1 .

Dari hasil perhitungan yang telah dilakukan maka diperoleh jawaban hasil observasi dengan kategori sangat baik $(80 \%$ - 100\%). Dengan demikian penggunaan pendekatan pembelajaran kelompok di Madrasah Tsanawiyah Negeri Pekan Heran Kecamatan Rengat Barat Kabupaten Indragiri Hulu dikategorikan sangat baik, yaitu 88,46\%.

Kemudian berkaitan dengan metode tes, dalam hal ini peneliti memberi tes berupa 5 soal tes obyektif mengenai materi pelajaran akidah akhlak.

Selain itu peneliti meminta hasil ulangan harian kelas $\mathrm{VII}^{4}$ (kelas eksperimen) dan kelas $\mathrm{VIII}^{5}$ (kelas kontrol) kepada guru akidah akhlak untuk mengetahui apakah kedua kelas tersebut benar-benar homogen yaitu memiliki tingkat kemampuan yang sama, sebagai syarat diberikannya soal post-test. Setelah dihitung, diperoleh hasil bahwa kedua kelas homogen. Peneliti memberikan soal post-test kepada kedua kelas yang dijadikan sampel pada penelitian ini untuk mengetahui melihat hasil belajar siswa. Adapun hasil tes siswa dapat dilihat pada tabel berikut ini:

Tabel. 1

Rekapitulasi hasil belajar siswa

\begin{tabular}{ccc}
\hline Responden & $\begin{array}{c}\text { Hasil Belajar } \\
\text { Kelas } \\
\text { Eksperimen }\end{array}$ & $\begin{array}{c}\text { Hasil Belajar } \\
\text { Kelas Kontrol }\end{array}$ \\
\hline $\mathbf{1}$ & $\mathbf{2}$ & $\mathbf{3}$ \\
\hline 1 & 90 & 80 \\
\hline 2 & 90 & 80 \\
\hline 3 & 90 & 80 \\
\hline 4 & 100 & 80 \\
\hline 5 & 80 & 70 \\
\hline 6 & 100 & 80 \\
\hline
\end{tabular}

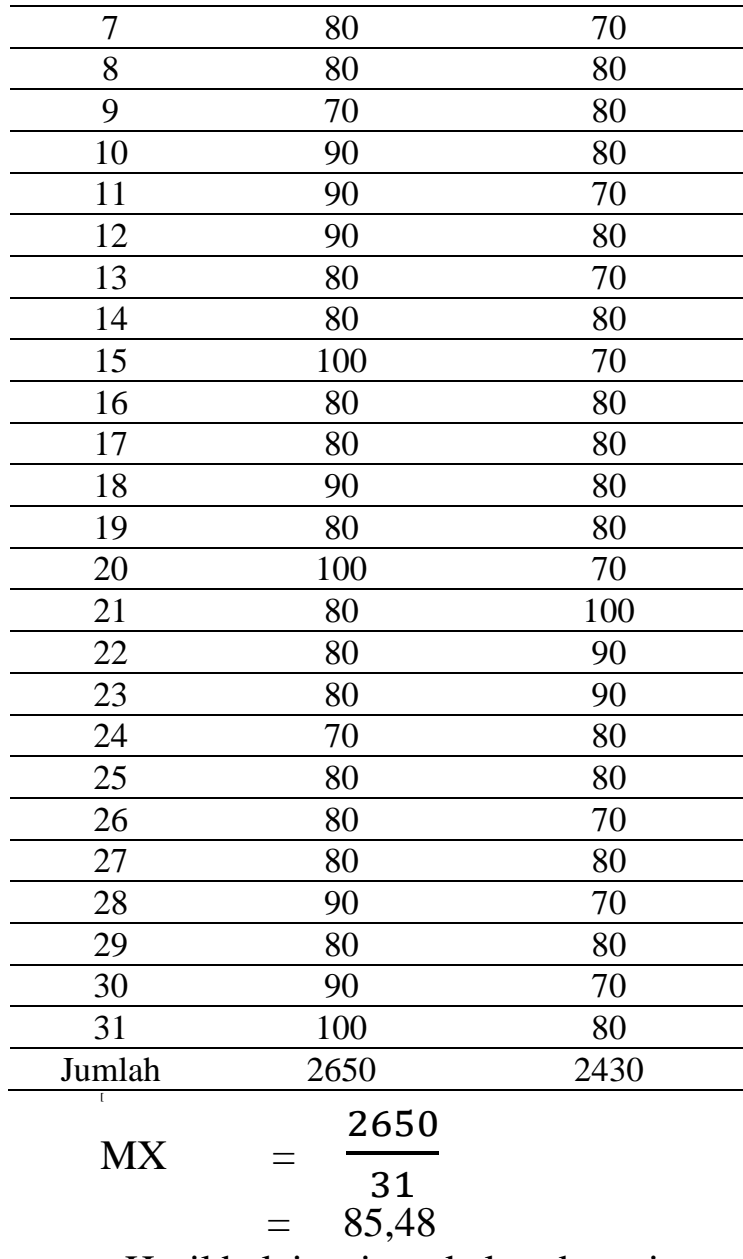

Hasil belajar siswa kelas eksperimen dikategorikan sangat baik, yaitu 85,48. Sedangkan hasil belajar siswa kelas kontrol dikategorikan baik, yaitu 78,39.

Dalam menganalisis data yang telah terkumpul, penulis menggunakan metode statistik. Analisis ini ditempuh dengan cara mengisi distribusi frekuensi yang telah dianalisis, kemudian dimasukkan dalam rumusan analisis deskripsi dengan komparasi. Rumus ini digunakan untuk menganalisis dengan menggunakan uji $t$ dengan melihat perbedaan yang signifikan antara hasil belajar yang diajar dengan pendekatan pembelajaran kelompok dengan hasil belajar siswa yang diajar dengan menggunakan metode konvensional. 
Pengaruh Penggunaan Pendekatan Pembelajaran Kelompok terhadap Hasil Belajar Akidah Akhlak Siswa Al Afif Hazmar, \& Marlian Marlian

Langkah selanjutnya adalah mempersiapkan perhitungan koefisien perbedaan yang signifikan antara hasil belajar yang diajar dengan pendekatan pembelajaran kelompok dengan hasil belajar siswa yang diajar dengan menggunakan metode konvensional Langkah-langkah itu dapat dilihat pada tabel berikut ini:

\section{Tabel. 2}

Tabel kerja untuk mencari koefisien hasil belajar siswa kelas eksperimen

\begin{tabular}{|c|c|c|c|c|}
\hline $\begin{array}{c}\text { No } \\
\text { Urut }\end{array}$ & $\mathbf{X}$ & $\mathbf{x}$ & $\mathbf{X}_{1}-\mathbf{X}_{1}$ & $\left(\mathbf{X}_{1}-\mathbf{X}_{1}\right)^{2}$ \\
\hline 1 & 90 & 85,48 & 4,52 & 20,4304 \\
\hline 2 & 90 & 85,48 & 4,52 & 20,4304 \\
\hline 3 & 90 & 85,48 & 4,52 & 20,4304 \\
\hline 4 & 100 & 85,48 & 14,52 & 210,8304 \\
\hline 5 & 80 & 85,48 & $-5,48$ & 30,0304 \\
\hline 6 & 100 & 85,48 & 14,52 & 210,8304 \\
\hline 7 & 80 & 85,48 & $-5,48$ & 30,0304 \\
\hline 8 & 80 & 85,48 & $-5,48$ & 30,0304 \\
\hline 9 & 70 & 85,48 & $-15,48$ & 239,6304 \\
\hline 10 & 90 & 85,48 & 4,52 & 20,4304 \\
\hline 11 & 90 & 85,48 & 4,52 & 20,4304 \\
\hline 12 & 90 & 85,48 & 4,52 & 20,4304 \\
\hline 13 & 80 & 85,48 & $-5,48$ & 30,0304 \\
\hline 14 & 80 & 85,48 & $-5,48$ & 30,0304 \\
\hline 15 & 100 & 85,48 & 14,52 & 210,8304 \\
\hline 16 & 80 & 85,48 & $-5,48$ & 30,0304 \\
\hline 17 & 80 & 85,48 & $-5,48$ & 30,0304 \\
\hline 18 & 90 & 85,48 & 4,52 & 20,4304 \\
\hline 19 & 80 & 85,48 & $-5,48$ & 30,0304 \\
\hline 20 & 100 & 85,48 & 14,52 & 210,8304 \\
\hline 21 & 80 & 85,48 & $-5,48$ & 30,0304 \\
\hline 22 & 80 & 85,48 & $-5,48$ & 30,0304 \\
\hline 23 & 80 & 85,48 & $-5,48$ & 30,0304 \\
\hline 24 & 70 & 85,48 & $-15,48$ & 239,6304 \\
\hline 25 & 80 & 85,48 & $-5,48$ & 30,0304 \\
\hline 26 & 80 & 85,48 & $-5,48$ & 30,0304 \\
\hline 27 & 80 & 85,48 & $-5,48$ & 30,0304 \\
\hline 28 & 90 & 85,48 & 4,52 & 20,4304 \\
\hline 29 & 80 & 85,48 & $-5,48$ & 30,0304 \\
\hline 30 & 90 & 85,48 & 4,52 & 20,4304 \\
\hline 31 & 100 & 85,48 & 14,52 & 210,8304 \\
\hline Jumlah & 2650 & & 0,12 & 2167,742 \\
\hline
\end{tabular}

Dari hasil pengolahan data tabel di atas maka diketahui hasil koefisien hasil belajar siswa pada bidang studi akidah akhlak kelas eksperimen adalah 8,36.
Tabel 3.

Tabel kerja untuk mencari koefisien hasil belajar siswa kelas kontrol

\begin{tabular}{|c|c|c|c|c|}
\hline $\begin{array}{l}\text { No } \\
\text { Urut }\end{array}$ & $\mathbf{X}$ & $\mathbf{X}$ & $\mathbf{X}_{1}-\mathbf{X}_{1}$ & $\left(\mathbf{X}_{1}-\mathbf{x} \mathbf{1}\right)^{2}$ \\
\hline 1 & 80 & 78,39 & 1,61 & 2,5921 \\
\hline 2 & 80 & 78,39 & 1,61 & 2,5921 \\
\hline 3 & 80 & 78,39 & 1,61 & 2,5921 \\
\hline 4 & 80 & 78,39 & 1,61 & 2,5921 \\
\hline 5 & 70 & 78,39 & $-8,39$ & 70,3921 \\
\hline 6 & 80 & 78,39 & 1,61 & 2,5921 \\
\hline 7 & 70 & 78,39 & $-8,39$ & 70,3921 \\
\hline 8 & 80 & 78,39 & 1,61 & 2,5921 \\
\hline 9 & 80 & 78,39 & 1,61 & 2,5921 \\
\hline 10 & 80 & 78,39 & 1,61 & 2,5921 \\
\hline 11 & 70 & 78,39 & $-8,39$ & 70,3921 \\
\hline 12 & 80 & 78,39 & 1,61 & 2,5921 \\
\hline 13 & 70 & 78,39 & $-8,39$ & 70,3921 \\
\hline 14 & 80 & 78,39 & 1,61 & 2,5921 \\
\hline 15 & 70 & 78,39 & $-8,39$ & 70,3921 \\
\hline 16 & 80 & 78,39 & 1,61 & 2,5921 \\
\hline 17 & 80 & 78,39 & 1,61 & 2,5921 \\
\hline 18 & 80 & 78,39 & 1,61 & 2,5921 \\
\hline 19 & 80 & 78,39 & 1,61 & 2,5921 \\
\hline 20 & 70 & 78,39 & $-8,39$ & 70,3921 \\
\hline 21 & 100 & 78,39 & 21,61 & 466,9921 \\
\hline 22 & 90 & 78,39 & 11,61 & 134,7921 \\
\hline 23 & 90 & 78,39 & 11,61 & 134,7921 \\
\hline 24 & 80 & 78,39 & 1,61 & 2,5921 \\
\hline 25 & 80 & 78,39 & 1,61 & 2,5921 \\
\hline 26 & 70 & 78,39 & $-8,39$ & 70,3921 \\
\hline 27 & 80 & 78,39 & 1,61 & 2,5921 \\
\hline 28 & 70 & 78,39 & $-8,39$ & 70,3921 \\
\hline 29 & 80 & 78,39 & 1,61 & 2,5921 \\
\hline 30 & 70 & 78,39 & $-8,39$ & 70,3921 \\
\hline 31 & 80 & 78,39 & 1,61 & 2,5921 \\
\hline \multicolumn{3}{|c|}{2430} & $-0,09$ & 1419,355 \\
\hline
\end{tabular}

Berdasarkan hasil olahan data di atas maka diketahui koefisien hasil belajar siswa kelas kontrol sebesar 2,5688.

Setelah harga t diketahui, kemudian akan diinterpretasikan dengan identifikasi bahwa apabila nilai $t$ yang diperoleh dari hasil angket sama atau lebih besar dari $\mathrm{t}$ dalam tabel, baik pada taraf signifikansi $5 \%$ atau $1 \%$, maka hasil penelitian ini menunjukkan signifikan, tetapi apabila nilai $t$ yang diperoleh ternyata lebih kecil dari nilai $\mathrm{t}$ dalam tabel, maka hasil 
penelitian non signifikan yaitu tidak terdapat perbedaan.

Untuk mengetahui nilai t dalam tabel, sebagai pedoman dasar pembuktian signifikan diperoleh hasil derajat kebebasan (dk) sebesar 60 yang dijadikan sebagai dasar pembuktian signifikansi. Berdasarkan tabel dapat diketahui bahwa dk sebesar 60 diperoleh $\mathrm{t}$ tabel pada taraf signifikansi $5 \%=2,00030$.

Karena $\mathrm{t}$ yang diperoleh dalam perhitungan yaitu thitung $=2,5688$ adalah lebih besar dari pada $t$ tabel taraf signifikansi $5 \%=2,00030(2,5688>$ 2,00030). Oleh karena itu, hipotesis nihil yang menyatakan tidak adanya perbedaan yang signifikan antara hasil belajar yang diajar dengan pendekatan pembelajaran kelompok dengan hasil belajar siswa yang diajar dengan menggunakan metode konvensional ditolak. Berarti kedua kelas yaitu kelas eksperimen dan kelas kontrol memiliki perbedaan yang signifikan antara hasil belajar yang diajar dengan pendekatan pembelajaran kelompok dengan hasil belajar siswa yang diajar dengan menggunakan metode konvensional.

\section{SIMPULAN}

Berdasarkan hasil penelitian dan pembahasan di atas dapat diambil kesimpulan bahwa penggunaan pendekatan pembelajaran kelompok di Madrasah Tsanawiyah Negeri Pekan Heran Kecamatan Rengat Barat Kabupaten Indragiri Hulu dikategorikan sangat baik (80\%-100\%) yaitu $88,46 \%$.

Adapun hasil belajar siswa kelas eksperimen juga dikategorikan sangat baik, yaitu 85,48. Sedangkan hasil belajar siswa kelas kontrol dikategorikan baik yaitu 78,39.

Terdapat perbedaan yang signifikan antara hasil belajar yang diajar dengan pendekatan pembelajaran kelompok dengan hasil belajar siswa yang diajar dengan menggunakan metode konvensional hal ini dilihat dari nilai $\mathrm{t}$ lebih besar dari pada $t$ tabel pada taraf signifikan 5\% yaitu 2,5688 > 2,00030.

\section{REFERENSI}

Arikunto, S. (2012). Prosedur Penelitian Suatu Pendekatan Praktek. Jakarta: Rineka Cipta.

Dimyati, \& Mudjiono. (2012). Belajar dan Pembelajaran. Jakarta: Rineka Cipta.

Indriana, A. P., \& Sasmiati, E. (2019). Pengaruh penggunaan model pembelajaran kelompok terhadap pembentukan sikap sosial. Pedagogi: Jurnal Pendidikan Dasar, 7,(11). Retrieved from http://jurnal.fkip.unila.ac.id/index.ph p/pgsd/article/view/19440

Nazir, M. (2013). Metode Penelitian. Bogor: Ghalia Indonesia.

Pingge, H. D., \& Wangid, M. N. (2016). Faktor yang mempengaruhi hasil belajar siswa sekolah dasar di kecamatan kota Tambolaka. Jurnal Pendidikan Sekolah Dasar Ahmad Dahlan, 2(1), 107-122. http://dx.doi.org/10.12928/jpsd.v2i2. 4947

Riduwan. (2004). Dasar-Dasar Statistika. Bandung: Alfabeta.

Rohmayanti, F., Yulistio, D., \& Utomo, P. (2019). Pelaksanaan pembelajaran kelompok kecil dan perorangan pada mata pelajaran Bahasa Indonesia siswa Kelas X di SMA Negeri 8 Kota Bengkulu. Jurnal Ilmiah KORPUS, 3(1), 21-32. https://doi.org/10.33369/jik.v3i1.734 3 
Suharni., Wahyuni, S., \& Salmah. (2020). Pengelolaan kelas pada model pembelajaran kelompok pada anak usia 5-6 tahun di TK IT Al- Mahira. PAUD Lectura: Jurnal Pendidikan Anak Usia Dini, 3(02), 68-77. https://doi.org/10.31849/paudlectura.v3i02.3990

Sudjana, N. (2012). Penelitian Hasil Proses Belajar Mengajar. Bandung: Remaja Rosda Karya.

Sugiyono. (2011). Metode Penelitian Pendidikan Pendekatan Kuantitatif Kualitatif, dan $R$ \& D. Bandung: Alfabeta.

Thobroni, \& dkk. (2011). Belajar dan Pembelajaran: Pengembangan Wacana dan Praktik Pembelajaran dalam Pembangunan Nasional. Yogyakarta: Ar-Ruz Media.

Waluya, T. (2015). Peningkatan aktivitas dan hasil belajar IPA materi pewarisan sifat dengan media kartu dogen. Jurnal profesi keguruan, 1(1), 18-28. Retrieved from https://journal.unnes.ac.id/nju/index. php/jpk/article/view/10210/6382 